\title{
21. Yüzyılda Türkiye'nin Bilim İletişimi Uygulamaları Üzerine Bir Çalışma
}

\author{
Şebnem Özdemir a, Dilara Nergishan Koçer ${ }^{b}$
}

\section{Özet}

Bilimin toplumların yaşamında merkezi bir konuma yerleşmesiyle, insanların bilim ve teknoloji ile ilgili konularda bilgiye ve bilimsel bakış açısına sahip olması zorunlu hale gelmiştir. Türkiye'nin akademik gündemine 1990'larda girmiş olan bilim iletişimi tam olarak 2004 yılında bir resmi politika olarak tescillenmiştir. Bu çalışmanın temel amacı, Türkiye'nin bilim iletişim politikalarının mevcut somut sonuçlarını ortaya koymaktır. Bu amaçla, önce bilim iletişimi ve ilgili kavramlar ile bilim iletişimin tarihsel gelişim süreci kısaca anlatılmıştır. Daha sonra Türkiye'de bilim iletişimi politikalarının tarihi özetlenmiş ve son olarak yeni bin yılda Türkiye'de kamu politikaları sonucu uygulamada olan bilim iletişimi formları olarak yazılı basın, televizyon, bilim merkezleri ve müzelerin bir derlemesi yapılmıştır. Çalışma göstermektedir ki Türkiye'de, bilimin olduğu kadar bilim iletişimi çalışmalarının da öncüsü TÜBİTAK (Türkiye Bilimsel ve Teknolojik Araștırma Kurumu)'tır. Bilim iletişimcileri yetiştirilmesi hususunda ise 2018 yılında merkezi yerleştirme ile öğrenci alan 226 yükseköğretim kurumunun ders müfredatı incelenerek üniversitelerde "bilim iletişimi" eğitimi verilip verilmediği tespit edilmeye çalışılmış; 226 üniversitede 10 adet benzer içerikte derse rastlanmıştır.
Anahtar Kelimeler

Bilim İletişimi

Bilim Politikası

TÜBİTAK

Bilim Muhabirliği

Makale Hakkında

Geliş Tarihi: 05.02.2020

Kabul Tarihi: 24.04.2020

Doi: 10.18026/cbayarsos.685206

\section{A Study on Turkey's Science Communication Practices in the $21^{\text {st }}$ Century}

\begin{abstract}
As science has been centrally located in the life of societies, it has become imperative that people have the knowledge and a scientific perspective on science and technology. Turkey's science communication has entered the academic agenda in the 1990s, it has been certified as an official policy, fully in 2004. The main objective of this study is to demonstrate concrete results of the current science communication policy of Turkey. For this purpose, firstly, science communication and related concepts, and the historical development process of science communication are briefly explained. Then summarized the history of science communication policies in Turkey, and then finally, print media, television, science centers, and museums are compiled as science communication forms that are being in practice as a result of public policies in the new millennium. The study shows that in Turkey, the pioneer of science communication as well as science is TUBITAK (The Scientific and Technological Research Council of Turkey). Regarding the training of science communicators, the course curriculum of 226 higher education institutions that enrolled students with central placement in 2018 was examined and it was tried to determine whether "science communication" education was given in universities; 10 similar content courses were found in 226 universities.
\end{abstract}

Keywords

Science Communication

Science Policy

The Scientific and Technological Research Council of Turkey

Science Journalism

About Article

Received: 05.02.2020

Accepted: 24.04 .2020

Doi: $10.18026 /$ cbayarsos.685206

a Dr. Öğr. Üyesi, Sivas Cumhuriyet Üniversitesi, orcid.org/0000-0003-0421-0833

b Dr. Öğr. Üyesi, Sivas Cumhuriyet Üniversitesi, orcid.org/0000-0002-4862-9698 


\section{Giriş \\ "Dünyada her şey için, maddiyat için, maneviyat için, hayat için, başarı için en hakiki yol gösterici ilimdir, fendir. İlim ve fennin dişında yol gösterici aramak gaflettir, cahilliktir, doğru yoldan sapmaktır.}

M. Kemal Atatürk (Bilim ve Teknik Dergisi Sayı 350)"

Milattan üç bin yıl önce kullanılmaya başlayan at arabası, saban ya da yelkenli tekneler, bir yenilik olmadan, neredeyse beş bin yıl boyunca kullanılmaya devam etmiştir. İnsanoğlu ancak 19. yüzyılda sanayi devrimi ile uygarlık tarihinde beş bin yıl öncekine benzer bir dönüşümü başlatabilmiştir. Pascal'ın 1642' de icat ettiği mekanik hesap makinesi ancak 19. yüzyılda kullanılmaya başlamıştır. Sanayi devrimiyle birlikte, bilimsel ve teknolojik gelişmeler, dünyanın her yerinde olmasa bile, ekonomik, toplumsal ve politik değişikliklere yol açmaya başlamıştır. Sıradan insanın bilime ilgi duymaya başlaması, bilimin popülerleşmesi, insanın bilimsel ve teknolojik gelişmelerin etkilerini kendi yaşamında görmeye başlaması 19. yüzyılda ortaya çıkmıştır.

Bugün, bilim ve teknolojideki gelişmeler ekonomiden halk sağlı̆̆ına, siyasetten beden güzelliğine kadar her alanı etkilemektedir. Sanayi devrimi ile başlayan bilgi birikimi zaman içerisinde medyanın bilime gösterdiği ilgiyi de arttırmıştır. Ama bilimsel bilgi ve teknolojiye asıl ilgi, 20. yüzyılda halkın bilim ve teknolojideki gelişmelerin sonucunu hayatında doğrudan ve daha fazla hissetmesi ile artış göstermiştir. Bilimsel gelişmeler sonucu dile giren her yeni kelime - dataizm, sibernetik ya da nanoteknoloj gibi - sıradan insanın dikkatini çekmese bile kanserojen, implant, kuş gribi ya da botoks gibi kelimeler herkesi ilgilendirir.

Bilimin toplumların yaşamında merkezi bir konuma yerleşmesiyle ilk kez ABD (Amerika Birleşik Devletleri)'nde bilim politikası oluşturma düşüncesi de ortaya çıkmış ve bu politika 1945 yılında uygulamaya konmuştur (Elmacl, 2015:56). Türkiye'nin resmi bir bilim politikası ortaya koyması ise 1983 yılında kabul edilen “Türk Bilim Politikası 1983-2003" belgesiyle mümkün olmuş, hatta proje hükümet programına da girmiş ancak hayata geçirilememiştir (s.65). 2004 yılında yayınlanan “Ulusal Bilim ve Teknoloji Politikaları: 2003-2023” belgesi bu açıdan çok önemlidir (TÜBİTAK, 2004). Bu belge Türkiye'nin resmi bilim politikasının ilk belgesidir.

Bu çalışmanın temel amacı da, 21. Yüzyılda Türkiye'nin bilim iletişimiyle ilgili kamu politikalarının mevcut somut sonuçlarını ortaya koymaktır. Bu amaçla, önce bilim iletişimi ile ilgili kavramlar ve bilim iletişiminin tarihsel gelişim süreci kısaca anlatılmıştır. Daha sonra Türkiye' de bilim iletişimi politikalarının tarihi özetlenmiş ve bilim iletişiminde TÜBİTAK'ın (Türkiye Bilimsel ve Teknolojik Araştırma Kurumu) kamudaki öncü rolü incelenmiştir. Bu çerçevede, çalışmada, bugün Türkiye'de kamu politikaları sonucu uygulamada olan bilim 
iletişimi formları olarak yazılı basın, televizyon, bilim merkezleri ve müze gibi ortamlarda bilimin halkla bağının kurulması için yürütülen çalışmaların nesnel sonuçları ortaya konulmaya çalışılmıştır.

Bu çalışma kapsamında bilim iletişimcilerinin yetiştirilmesi/eğitimi konusu da ele alınmıştır. Çünkü yazılı basın olsun, görsel-işitsel medya olsun bu kurumların bilim ile ilgili konuları aktaracak mecralar olması kadar, bu mecralarda bilgiyi şekillendiren ve sunuma hazır hale getiren aracılar olarak yazarlar/muhabirler aynı derecede önem taşımaktadır. Nitekim bu husus politika yapıcıların da dikkatinden kaçmamıştır. 2004 yılında yayınlanan ve 20 yıllık bir zaman dilimi içinde izlenecek politikaları belirleyen "Ulusal Bilim ve Teknoloji Politikaları: 2003-2023" belgesinin 1şığında hazırlanan, 2011-2016 Bilim ve Teknoloji İnsan Kaynağı (BTIK) Stratejisi ve Eylem Planı bu konuya da eğilmiştir. Eylem Planı kapsamında 21 Aralık 2012 tarihinde Yüksek Öğretim Kurumu (YÖK) tarafından bütün üniversitelere gönderilen bir yazıda, "bilim muhabirliği" ve "bilim muhabiri" yetiştirmenin öneminden bahsedilmektedir. Yazıda iletişim fakültelerinin müfredat programlarında bu içerikte bir ders bulunup bulunmadığı ve böyle bir dersin konulması ile ilgili görüş sorulmuştur. Bu plan çerçevesinde "Bilim muhabirliği eğitimlerinin yaygınlaştırılarak, donanımlı bilim, teknoloji muhabirlerinin yetişmesinin sağlanması" yetiştirilmesinin hedeflendiği tüm yükseköğrenim kurumları ile paylaşılmıştır. $\mathrm{Bu}$ planın nihai amacı toplumda bilim-teknoloji kültürünün yaygınlaştııılmasıdır (TÜBİTAK Bilim, Teknoloji ve Yenilik Politikaları Daire Başkanlığı, 2010: 26). Dolayısıyla, çalışma kapsamında, YÖK'ün yazısı baz alınarak Türkiye'deki tüm yükseköğrenim kurumları, fakülte ve yüksekokullarındaki bütün lisans bölümlerinin müfredat programı taranarak bilim iletişimi ile ilgili derslerin incelemesi yapılmış ve bilimin haberleştirilmesini ve farklı medyalarda sunumunu gerçekleştirecek aracılar, aktarıcılar olarak bilim iletişimcilerinin/muhabirlerin yetiştirilmesi ile ilgili gelişmeler ya da son durum ortaya konulmaya çalışılmıştır. Çalışma kapsamında yüksek lisans programlarının da incelenmesi hedeflenmişse de bu programlarda ders içeriklerin tam olmadığ görülmüştür. Lisans programlarının tam listesi ÖSYM tarafından kamuya açık bir şekilde yayınlanmaktadır. Ancak yüksek lisans ve doktora programları YÖK tarafından yönetilmekte ve YÖK bu programların bir listesini oluşturmamış ve kamuyla paylaşmamıştır. Bununla birlikte yapılan genel araştırmada görülmüştür ki bazı üniversiteler program müfredatlarını kurumsal web siteleri üzerinden paylaşmaktadır. Ama çoğunlukla yüksek lisans ve doktora program ders içerikleri çoğu üniversite tarafından paylaşılmamaktadır. Bu yüzden çalışma sadece lisans programları ile sınırlandırılmıştır.

\section{Yöntem}

Enformatif bir çalışma olarak bu makale, Türkiye'nin 21. Yüzyıldaki bilim iletişimi politikalarının somut sonuçlarını ortaya koymayı amaçlamaktadır. Çalışma, aslen veri toplamada doküman incelemesi yönteminin kullanıldığı nitel bir araştırma olup, müfredat analizi kısmında yapılan çalışma ile kısmen nicel analiz de içermektedir. Verilerin analizinde betimsel analiz yöntemi kullanılmıştır. "Nitel araştırma", doküman analizi, gözlem veya görüşme gibi veri toplama yöntemleriyle alg1 ve olayların bütüncül bir biçimde ortaya konmasına yönelik nitel bir süreç izleyen araştırmadır (Şimşek ve Yıldırım, 2012: 45). Bu süreçte, "Doküman incelemesi, araştırılması hedeflenen olgu veya olgular hakkında bilgi 
içeren yazılı materyallerin analizini kapsar." (s. 217) ve kendi başına da kullanılabilen bir veri toplama yöntemidir (s.47). Strauss ve Corbin'in önerdiği gibi, nitel verilerin analizinde kullanılan yöntemlerden biri betimsel analizdir. Betimsel analiz, araştırmanın kavramsal yapısının önceden açıkça belirlendiği araştırmalarda kullanılır (s. 255).

Bu çalışmada öncelikle kavramsal çerçevenin belirlenmesi için "bilim iletişimi" ve ilişkili kavramlar tanımlanmış, tarihsel gelişim sürecine yer verilmiştir. Daha sonra Türkiye' de bilim ve bilim iletişimi ile ilgili politika yapım süreci incelenmiştir. Son olarak da, günümüzde bilim iletişimine yönelik politikaların fiili uygulamaları ve somut çıtıları alt başlıklar halinde sıralanmıştır. Bu çerçevede, bilimsel makale ve kitapların yanısıra, kurum raporları, strateji planları, web siteleri gibi birincil ve ikincil veri kaynaklarından yararlanılmıştır. Ayrıca, YÖK tarafından 2012 yılında üniversitelere gönderilmiş olan "bilim muhabirliği" dersinin müfredat programlarındaki yeri ile ilgili yazısına istinaden, Türkiye'deki üniversitelerin müfredat programlarının araştırılması gerekli görülmüştür. Bu amaçla, 2018 yılı itibariyle mevcut tüm üniversitelerin lisans düzeyindeki derslerinin bir taraması yapılarak, bilim muhabirliği/bilim iletişimi ile örtüşen derslerin sayısı saptanmıştır: 2018 yılında 226 üniversitede 10 adet benzer içerikte derse rastlanmıştır. Bu veri de çalışmanın bilim iletişimi eğitimi ile ilgili bölümünde kullanılmıştır.

\section{Sinirlıliklar}

Bu çalışmanın araştırması iki ana kısımdan oluşmaktadır. Birinci kısımda Türkiye'de devlet eli ile yapılan bilim iletişimi ve bilim iletişim formları incelenmiştir. Bu kapsamda özel kurum ya da kişilerin yapmakta oldukları bilim iletişimi faaliyetleri (dergiler, ortam akışı (podcast), televizyon, bilim merkezleri, müzeler, sosyal medya hesapları vb.) çalışma kapsamına alınmamıştır.

Çalışmanın ikinci kısmı ise nicel araştırmadan oluşmaktadır. Bu kısımda örneklem olarak 2018 yılında ÖSYM (Ölçme, Seçme ve Yerleştirme Merkezi) tarafından merkezi yerleştirme ile öğrenci alan yükseköğretim programları alınmıştır. Bu kurumların lisans düzeyinde eğitim veren ilgili bölümleri ve bu bölümlerde verilen bilim iletişimi ile ilgili dersler irdelenmiştir. Milli Eğitim Bakanlığı'na bağlı okullar çalışmaya dâhil edilmemiştir. Yükseköğretim kurumları kapsamında; yüksek lisans ve doktora programları da çalışmaya dâhil edilmemiştir. Zira yüksek lisans ve doktora programları enstitülere bağlı olarak yürütülmekte olup bu programlar ve müfredatın tamamına ilişkin bilgiye ulaşmak olası değildir.

\section{Bilim İletişimi}

Burns v.d. (2003:183) bilim iletişimi ve ilişkili kavramlarla ilgili olarak akademik yazında bir belirsizlik olduğundan söz ederler. Nitekim tarih, coğrafya, dilbilim ya da psikoloji birer bilim dalıdır ancak günlük dilde "bilimdeki gelişmeler" dendiğinde bu bilim dallarının akla gelmeyeceği açıktır. Diğer yandan teknoloji ve tıp "pür/saf bilim" (pure science) olarak tanımlanmaktadır. Matematik "bilim dili” olarak görülürken, mühendislik "pür bilim” için bir "link" (bağlantı ya da aracı) olarak kabul edilmektedir (s. 185) Türk Dil Kurumu sözlügünde 
bilim “ Evrenin veya olayların bir bölümünü konu olarak seçen, deneye dayanan yöntemler ve gerçeklikten yararlanarak sonuç çıkarmaya çalışan düzenli bilgi" (https://www.sozluk.gov.tr/) şeklinde tanımlanmıştır. Dolayısıyla bilim, "pür bilim"den daha geniş bir alanı kapsamaktadır. Çalışmaya açıklık kazandırmak için her şeyden önce bilim iletişimi için "bilim" denildiğinde ne anlamak gerektiğini kesinleştirmek gereklidir. Bilim iletişimi bağlamında "bilim", matematik, istatistik, mühendislik, teknoloji, tıp ve ilişkili alanları ifade etmektedir (s. 185).

Bilim iletişimi ve bilim gazeteciliği ile ilgili de çeşitli tanımlar bulunmaktadır. Erdoğan (2007) kuramsal açıdan bilim iletişimi ve bilim gazeteciliğinin farklı kavramlar olduğunu belirtir. Bilim iletişimi, "yaygın ve yerel basında sunulan "bilimle ilgili tüm içerikleri kapsayan" anlamını ifade ederken, bilim gazeteciliği "Gazetelerde bu tür içerik biçimlendirme ve sunma faaliyeti" (s. 121-122) olarak tanımlanır. Dolayısıyla Erdoğan bilim iletişimini basınla sınırlandırır. Burns ve arkadaşları da bilim iletişimini, amacı bilimsel farkındalık, anlayış ve bilimsel kültür olan bir "süreç" olarak tanımlarlar (Burns, v.d.,2003:190). Dolayısıyla bilim iletişimi, bilginin üretilmesi, yayılması, kullanılması süreçlerini kapsayan, bu sırada sosyal ve kültürel unsurlardan etkilenen ve onları etkileyen dinamik bir faaliyet alanıdır (Burakgazi, 2017). Bilimsel ve teknolojik süreçler, bu süreçlere dair politikalar ile bu süreçleri gerçekleştiren bilim insanları ve diğer kurumsal yapıları sıradan insanlarla bağlantılandıran her türlü içeriğin, özellikle medya aracılığıyla dolayımlandığı ve etkileşimin gerçekleştirildiği iletişimdir (Dursun, 2010:2).

Dolayısıyla en geniş tanımıyla bilim iletişimi formları/kaynakları/araçları çok çeşitlidir; gazete ve dergiler, kitaplar, televizyon, internet, bilim merkezleri, müzeler, konferanslar, bilim festivalleri vb. gibi. Tüm bu ortamlar, bilim insanları ve bilimsel bilgi ile toplum arasındaki ilişkiyi kurmaya yarar.

Halkın bilimle buluşmasını en kolay ve hızlı sağlayan ortamlar ise kitle iletişim araçlarıdır. Bu açıdan bilim gazeteciliği büyük önem taşır. Bilim gazeteciliği kısaca, bilimle ilgili habercilik faaliyeti şeklinde tanımlanabilir. Dolayısıyla bilim gazetecisi, bilim iletişimini gazete, televizyon, blog gibi her çeşit medya aracılığıyla gerçekleştiren kişidir (Bauer, v.d.., 2013:7; Cassany, v.d., 2018:12) ve halk ile bilim arasında iletişimi kurmada gazetecilik "anahtar" kelimedir (Lynch, v.d., 2014: 480). Bilimi medya aracılığıyla aktarma işi "bilim gazeteciliği", "bilim haberciliğii", "bilim muhabirliği" kavramlarıla ifade edilmektedir (Bauer, v.d., 2013; Fahy ve Lisbet, 2011). Bu kavramlar birbirlerinin yerine kullanılmakta ya da aynı metin içinde birlikte kullanıldıklarına rastlanmaktadır.

Bilim iletişiminin 18. yüzyılda ortaya çıktığı söylenebilir. Kamuya açık dersler ve konferanslarla kültürel yaşamın bir parçası haline gelmeye başlayan bilim, 19. yüzyılda ilk kez gazetelerde haber olmaya, popülerleşmeye başlamış, bu yüzyılın ikinci yarısından sonra bilim iletişimi yaygınlaşmaya başlamıştır (Nelkin, 1987; Dursun, 2010:3). 20. yüzyılın ortalarında bilimsel gelişmelerdeki artış, demokratik işleyiş̧in güçlenmesi, kitle iletişim araçlarının yaygınlaşması gibi gelişmeler toplumla bilimin buluşturulması düşüncesini artık bir gereklilik 
olarak ortaya çıkarmıştır. 1980'lerde bilim iletişimi kavramı önem kazanmaya başlamış, bilimsel ve teknolojik gelişmelerin halka iletilmesi ile ilgili çabalar çeşitli yaklaşımlar kapsamında değerlendirilmiştir (Burns, v.d., 2003; Dursun, 2010; Akoğlu, 2011). Bilim iletişimi literatüründe 1980 'lerde bilimsel ve teknolojik bilgileri halka basitçe anlatma/aktarma anlayışı "Halkın Bilimi Anlaması/Kavraması" (Public Understanding of Science/PUS) anlayışı şeklinde tanımlanmıştır. Bu yaklaşımda iletişim tek yönlüdür. Bu yaklaşımda medyanın işlevi halkı bilimsel yöntem ve uygulamalar hakkında eğitmek olarak görülmüştür. 1990'larda ortaya çıkan yaklaşımla, insanlara bilimsel gelişmeleri aktarmak ve onlara bu süreçleri kabul ettirmek anlayışından uzaklaşılmaya başlamıştır. Daha eşitlikçi bir ortamda, iki yönlü etkileşime dayalı, "Halkın Bilim ve Teknolojiyle Bağlantısı" (Public Engagement with Science and Technology/PEST) anlayışı ortaya çıkmıştır.

Günümüzde, halkın bilim ve teknolojiyle bağlantısı anlayışı ile yazılı basın ve televizyonlarda bilimsel haberler daha fazla yer almaya, insanların bu konulardaki görüşleri önem kazanmaya başlamış, bilimsel ve teknolojik gelişmelerden etkilenen halkın bu konulardaki politikalarla ilgili gelişmeleri takip edebilmeleri ve karar alma süreçlerine katılmaları bir gereklilik haline gelmiştir.

\section{Bilim Üretimi/Üreticileri}

19. yüzyıla kadar daha çok bireysel bir çalışma alanı olan bilim 20. yüzyılda kurumsallaşmaya ve ticarileşmeye başlamıştır. Bilim yapmanın pahalı bir iş haline gelmesi, araştırmacıları fon kaynaklarına bağımlı hale getirmiştir ki bu da bilimi hükümetler tarafından yönetilir bir alana dönüştürmüştür (Dursun, 2010:5). Bilimsel alan devlet tarafından yönetilmekte ya da yönlendirilmektedir (Fuller, 1999:8). Çünkü ulusal ve uluslararası politikalar üzerinde bilimsel gelişmelerin etkisi vardır. Ulusal zenginlik ve endüstri bilim üzerine inşa edilmiştir (Royal Society, 1985).

Bilim genel olarak eğitim kurumları tarafından üretilmektedir ki bu eğitim kurumları da devletin kontrolündedir. Bilim üretiminin en büyük paydaşı olan devlet aynı zamanda bilimsel ve teknolojik yeniliklerin de en büyük alıcısıdır. Telgrafın, radyonun, internetin ilk kullanıcısı hep devletler olmuştur. Silah üreticilerinin de en büyük müşterisi devlettir. Elon Musk'ın yaptığı uzay aracı-otomobil NASA (Amerika Birleşik Devletleri Ulusal Havacılık Uzay Dairesi)'nın Mars projesi için geliştirilmiştir. Dolayısıyla genel olarak bilim, devletin bilim politikaları çerçevesinde üretilmektedir. Bu süreçte resmi eğitim kurumlarının yanı sıra özel kurum ve şirketler bilim üretimi sürecinin bir parçasıdır.

\section{Bilimsel Bilginin Toplum İçin Önemi}

Bilim ve teknoloji bireylerin yaşamında, çevreden ekonomiye her alan üzerinde önemli etkiye sahiptir (Fuller,1999:8). Bilim ve teknolojideki gelişmeler toplumsal, ekonomik ve siyasal 
sistem üzerinde değişikliklere yol açar. Yeni meslekler, hatta endüstriler ortaya çıkarken toplumsal yaşam biçimi ve ilişkiler değişmekte ve devlet aygıtı bütün bu gelişmeler üzerinde düzenleyici işlev görmektedir (Nelkin, 1994; Burakgazi, 2017). Bilimsel gelişmeler sanayi devrimi sonrasında artarak yaygınlaşırken toplumlar aynı süreç içinde modernleşip demokratikleşmiştir.

İngiltere'de 17. yüzyılda kurulmuş olan "Royal Society" adlı dernek 1985 yılında bilimin toplumsal işlevi ve toplumun bilimi algılama biçimine ilişkin bir araştırma yayınlamıştır. Rapor demokratikleşen toplum açısından bilimin insanlar için önemini açıkça ortaya koymaktadır: kamuoyu demokrasilerde karar alma süreçlerinde büyük etkiye sahip olduğu için bilimsel bakış açısına da sahip olması gerekmektedir; toplumun bilimi anlaması toplumun niteliğinin artışında, kişisel kararların alınmasında ve bireysel yaşamların zenginleştirilmesinde son derece önemlidir (s. 7).

19. yüzyıl Batı'da bilimsel gelişmelerin büyük bir aşama kaydettiği ve bilimle ilgili ilk haberlerin yayınlanmaya başladığı dönemdir. Ama ancak 2. Dünya Savaşı'ndan sonra devletlerin bilimi planlamalarına dâhil etmeye başlamış, politika haline getirmiştir. Çünkü bilim artık ekonomik geri dönüşü olan bir yatırım alanı olarak görülmeye başlamıştır. Diğer yandan ABD, İngiltere, Fransa gibi Batılı ülkelerde bilim yazarları dernekleri, bilimsel ve teknik müzeler kurulmaya başlamıştır. İngiltere'de Kraliyet Cemiyeti'nin 1985 yılında yayınladığı rapor bilim ve sıradan insan arasındaki ilişkiyi geliştirmeyi amaçlamış ve resmi politika konusu olmuştur. ABD'de Amerikan Bilimin Geliştirilmesi Derneği (American Association fort he Advencement of Science), Ulusal Bilim Vakfı (National Science Foundation) gibi kurumlar ortaya çıkmıştır (Dursun, 2010). 20. Yüzyılda ABD ve Avrupa ülkelerinde fizik, doğa, astronomi gibi pozitif bilim alanlarındaki popüler bilim kitaplarının yayıncılık piyasasında önemli bir payı vardır (Dursun, 2018: 89)

Dolayısıyla insanların kendi yaşamlarında bilim, teknoloji ve bunlarla ilgili politikaların etkisini hem daha fazla hissetmesi hem de bu politikalarda belirleyici etkiye sahip olması, bilimin halk tarafından anlaşılmasını gerekli hale getirmiştir. Bu aynı zamanda bu sorundur çünkü bilim insanı/bilim ile toplum arasında kopukluk vardır. Bilim ve insan/toplum arasındaki mesafenin kapatılabilmesi, dolayısıyla günlük pratik işler ya da siyasal ve yönetsel sorunlar hakkında akıcı karar verebilmesi, rasyonel davranışta bulunması için medya aracılığıly aktarılan bilgiye ihtiyacı vardır. Bu çerçevede, bir olgu olarak bilim iletişimi 21. yy. insanı için büyük önem taşımaktadır. Bu yüzden insanlar artık sadece okuryazar değil, “bilimsel medya okuryazarı" da olmak zorundadır (Royal Society, 2010:13).

"Bilimsel söylemin doğasının karmaşıklığı, bilimin gittikçe daha merkezi bir konum elde etmesi ve sağlıklı ve sürdürülebilir yaşamla ilgili tartışmalar etrafındaki politikalar" (Murcott ve Williams, 2012:154) bilimsel iletişimi, hem yöneticiler hem bireyler için önemli daha doğrusu bir zorunluluk haline getirmiştir. İnsanların bilimsel konularda bilgi sahibi olması hem kişisel yarar sağlar hem de toplumsal ve siyasal meseleler açısından gereklidir. Bilim insanlara toplumsal ve çevresel sorunlarla ilgili çözüm üretiminde yol göstericidir. Diğer 
yandan, demokratik bir toplumda kamuoyu, karar alma süreçleri açısından çok önemli bir etkendir. Karar alıcılar kadar vatandaşların da toplumsal meselelerle ilgili bilimsel bakış açısını anlamaları gerekir (Nelkin, 1994:10; Royal Society, 1985:10).

\section{Türkiye Bilim Politikaları ve Bilim İletişimi}

20.yüzyılın ortasına gelindiğinde ülkeler arasındaki teknoloji farkı büyümüş, teknolojisi güçlenen ülkeler diğerlerine üstünlük sağlamıştır. Bu süreçte, önce $A B D$ olmak üzere, devletler kendi bilim politikalarını oluşturmaya ve uygulamaya koymaya başlamıştır. Bu politikalar sayesinde bilim ve teknoloji sistemlerini kuran ülkeler hızla kalkınmıştır (Elmacı, 2015: 57). Türkiye'de bilim politikasının ortaya çıkmasını sağlayan, beş yıllık kalkınma planlarıdır. TÜBİTAK, Türkiye' de planlı ekonomi döneminin başında, I. Beş Yıllık Kalkınma Planı çerçevesinde, 1963 yılında kurulmuştur. Türkiye'nin bilim politikasını oluşturma ve gerçekleştirme amacıyla kurulan kurum, bilim politikası belgesi hazırlama amacıyla 1966 ve 1971 yıllarında OECD ile temasa geçmiş, çalışmalar yapmış ancak bu çalışmalar sonuçlandırılamamıştır. Yine de somut bir bilim politikası belgesi olmamakla birlikte, 1980'le kadar doğa bilimlerinde temel ve uygulamalı araştırmalar desteklenmiştir (Elmacı, 2015:58).

Bilimsel medya okuryazarlığı, halkta bilimi destekleyici tutum yaratılması, halkın bilimsel ve teknolojik politikalarla ilgili karar alma süreçlerine katılımı gibi bilim iletişiminin parametreleri (Dursun, 2010:23) bir ülkenin resmi bir bilim politikasına sahip olmasıyla, bu parametreleri gerçekleştirecek kurumların varlığıyla mümkündür. TÜBİTAK (Türkiye Bilimsel ve Teknolojik Araştırma Kurumu) bu amaçla kurulmuştur. Bilim politikaları ile ilgili uygulamalara bakıldığında ilk adımın ABD tarafından atıldığı görülür. ABD'nin bilim politikası oluşturmaya ve uygulamaya koyduğu tarih 1945'tir (Elmac1, 2015:56). Türkiye'nin resmi bilim politikası belgesi ancak 1983 yılında hazırlanmış, “Türk Bilim Politikası 1983-2003” belgesi hükümet programına girmiştir, ancak hemen uygulamaya konulamamıştır (s.65).

Dolayısıyla, 2000'li yıllar Türkiye için sadece bilim politikaları açısından değil bilim iletişimi açısından da bir dönüm noktasıdır. Batı' da 1980'li yıllarla birlikte halkın bilimi kavramasını sağlama yönünde ortaya çıkan yaklaşım, Türkiye' de 2000'li yılların başında görülmeye başlar. TÜBİTAK tarafından hazırlanan “Ulusal Bilim ve Teknoloji Politikaları: 2003-2023 Strateji Belgesi” 2004 yılında yayınlanmış, böylece kurum Türkiye'de bilimi yayma, halkı bilimle buluşturma faaliyetini resmi olarak gerçekleştirmeye başlamıştır. Belgenin giriş kısmında Türkiye'nin bir yol ayrımında olduğu, ancak geleceğin "teknolojilerinde egemenlik sağlayarak" uluslararası refah toplumlarının bir üyesi olabileceği ve yarını garanti altına alabileceği belirtilerek, 2023'e uzanan süreçte bilim ve teknoloji politikalarının belirlenmesi için TÜBİTAK'ın görevlendirildiği ifade edilmiştir. Belgede, "arzu edilen geleceğin" yaratılması için bilim ve teknolojide yetkinleşmenin gerektiği, bunun için de "Toplumsal katmanlarda farkındalık yaratma" gerektiği belirtilmiştir. Bu farkındalık yaratma görevinin bir paydaşı olarak da medya işaret edilmiştir. Bilgi temelli bir ekonominin kurulması için toplumu bilinçlendirecek içeriği topluma iletecek olan medyanın, bilgilendirilmesi, 
bilinçlendirilmesi ve teşvik edilmesi de TÜBİTAK'ın strateji planının bir parçasıdır (TÜBİTAK, 2004:32)

$\mathrm{Bu}$ Ulusal Strateji Planı'nda belirlenen hedefler doğrultusunda, bilim iletişiminin gerçekleştirilmesi, bilimle halkın bağının kurulabilmesi yönünde, mevcut olanlara yenileri eklenerek medyadan proje desteğine kadar çok çeşitli araçlar hayata geçirilmeye çalışılmaktadır.

\section{Eğitim}

Nelkin (1994) 20. yy. bitmek üzereyken bile “Çoğu insan için bilimin gerçekliği basında okuduklarından ibarettir" der (s. 11). İnsanlar bilimsel ve teknolojik gelişmelerle ilgili bilgileri medyanın bunları şekillendirdiği haliyle algılarlar. Dolayısıyla, insanların hayatlarını etkileyebilecek kadar önemli kararları alabilmesi bir oranda medyaya bağlıdır.

Bu bağlamda bilim ile toplum arasında köprü rolü oynayan medyanın bu konulardaki bilgiyi ne kadar doğru anlattığı, aktardığı ve halkın bu bilgilerin ne kadarını ve doğru anladığı önemli bir sorundur. Yerel ve ulusal basın ve televizyonlar hızla gelişen teknoloji ve bilimsel araştırmaların yoğunluğu sebebiyle, sayfalarında-yayınlarında sık sık bu gelişmelere dair haberlere yer vermektedir. Ancak bu haberler çoğunlukla belli amaçlar için hazırlanmış paket ürünlere dayandırılmaktadır. Üstelik bu bilgi de örneğin gazeteye girerken kırpılmakta, dolayısıyla eksik, yanlış, yanıltıcı bir şekle bürünmektedir. Oysa günümüzde bilimin insan yaşamı için taşıdığı önem düşünüldüğünde halkın bilimi, bilimin önemini anlaması bir zorunluluktur. Bu bağlamda "bilim iletişimi" sadece politika yapıcıların değil akademik dünyanın da çalışma alanı haline gelmeye başlamıştır.

Bilim iletişiminin bir disipline dönüşmesiyle ilgili olarak; Trench ve Bucchi, bilim iletişiminin son çeyrek yüzyılda fen bilimleri, sosyal bilimler, kitle iletişimi, müze çalışmaları gibi akademik ve profesyonel aktivitelerin kesişimi olacak şekilde gelişme gösterdiğini ve akademik yapıda yer bulduğunu belirterek, bilim iletişiminin yükseköğretim programları ile ilintili uygulama alanı olarak isimlendirilmesinin ardından formel bir çalışma alanı haline geldiğini ifade eder (Trench ve Bucchi'den akt: Burakgazi, 2017:235).

2013 yılında yayınlanan "Global Science Journalism Report" (Bauer, et al.) dünyadaki bilim gazetecileri profili ve onların çalışma koşulları hakkında aydınlatıcıdır. Büyük çoğunluğu Güney Amerika, Avrupa/Rusya, Asya ve Afrika olmak üzere ABD ve Kanada'daki bilim gazetecileri arasında yapılmış olan çalışmaya göre, dünyadaki bilim gazetecilerinin \%26'sı bilim gazeteciliği eğitimi almıştır. Bilim gazetecileri arasında formel eğitim almış olanların oranı ABD, Avrupa ve Kanada'da, diğerlerinden daha yüksektir. Bunların arasında doktora (Ph.D.) eğitimlilerin oranı \%30 düzeyindedir. Dolayısıyla endüstrileşme düzeyi yüksek olan kuzeybatı ülkelerinde bilim gazeteciliği alanında uzmanlaşmış olanların, eğitim seviyesinin de dünyanın geri kalanına göre daha yüksek olduğu anlaşılmaktadır.

Cassini ve arkadaşlarının yaptığı çalışma İspanya'daki bilim gazetecileri oranının dünya ortalamasının üstünde olduğunu göstermektedir. Bilim gazetecilerinin \%37'i hem bilim hem 
gazetecilik eğitimi almıştır. Ancak araştırmaya katılanların \%59'u "iyi bilim gazetecisi olmak için” bilim eğitiminin gerekli olmadığını düşünmektedir (Cassini, v.d., 2018:12-13). Avustralya'da ise bilim gazeteciliği 1990'larla birlikte önemli bir gelişme göstermiştir (Metcalfe ve Gascoigne, 1995). Bilim ve teknoloji alanında uzmanlaşmış gazetecilerin oranı \% 6 olmakla birlikte buradaki bilim gazetecileri profiline bakıldığında, kadınların erkeklerin iki katı sayıda olduğu, genel olarak diğer gazetecilerden daha eğitimli oldukları ve daha çok kazandıkları görülmektedir.

Türkiye' de geleneksel medyada "bilim gazetecisi/muhabiri”, "bilim haberciliğii” şeklinde bir uzmanlık alanı yoktur. Medyada yaşanan bu boşluk, kitle iletişim araçları üzerinden tanıtılan çeşitli ürünlerin (ör: zayıflama hapları) tanıtılmasıyla adeta tehlikeli bir hal almaktadır. Ancak dünyadaki gelişmelere paralel olarak Türkiye' de de bilim ve teknoloji alanındaki gelişmelerin toplumların ve devletlerin gelişme düzeyine etkisi fark edildiğinden, 2000'lerin başından itibaren devletin bilim iletişimine verdiği önemde artış olmuştur.

YÖK'ün 2012 yılında üniversitelere göndermiş olduğu yazı bu açıdan önemlidir. Bilim muhabirliği eğitiminin yaygınlaştırılmasının hedeflendiğini ortaya koyan yazı, bilim iletişiminin devlet politikası olarak benimsendiğinin önemli bir göstergesidir.

Çalışma kapsamında, YÖK'ün planı baz alınarak Türkiye'deki tüm yükseköğrenim kurumları, fakülte ve yüksekokullarındaki bütün bölümlerin müfredat programı taranarak bilim iletişimi ile ilgili derslerin incelemesi yapılmış ve yükseköğretimde gazetecilik ve bilim ilişkisi tespit edilmeye çalışılmıştır.

Aslında Türkiye'de bununla ilgili ilk girişim İstanbul Üniversitesi Edebiyat Fakültesi Bilim Tarihi Bölümü'nde başlamıştır. Bu bölümde 1995-96 yıllarında "Bilim Gazeteciliği" dersi verilmeye başlanmıştır (Koloğlu, 1997:VII). Dersleri veren, tarihçi-gazeteci Orhan Koloğlu aynı zamanda, bilim tarihi alanında ilk sivil toplum kuruluşu olan Türk Bilim Tarihi Kurulu (TBTK)'nın da üyesidir. Ancak bu dersin uzun ömürlü olmadığı anlaşılmaktadır. Diğer yandan dersin, İletişim Fakültesi bünyesinde değil de Edebiyat Fakültesi bünyesinde verilmesi, konunun öneminin henüz anlaşılamadı̆̆ı göstermektedir.

Bu çalışma kapsamında, hâlihazırda ÖSYM (Ölçme, Seçme ve Yerleştirme Merkezi) tarafından merkezi yerleştirme ile öğrenci alan yükseköğretim programları incelenmiş, bu programlar dâhilinde yükseköğretim kurumlarının müfredatları incelenerek bilim iletişimi ile ilgili dersler tespit edilmiştir. 2018 tarihinde merkezi yerleştirme ile öğrenci alan Türkiye'deki tüm devlet ve vakıf üniversiteleri, bu üniversitelere ek olarak yine merkezi yerleştirme ile öğrenci alan tüm KKTC (Kuzey Kıbrıs Türk Cumhuriyeti) üniversiteleri, araştırma kapsamına dâhil edilmiştir.

Çalışma kapsamında incelenen üniversitelerin web siteleri üzerinden ilgili fakülte ve bölümlerin müfredatlarına ulaşılarak bilim iletişimi ile ilgili dersler tespit edilmiştir. Araştırma kapsamının asıl odağı iletişim fakülteleri olmakla birlikte bazı üniversitelerde iletişim ile ilgili bölümlerin (Halkla İlişkiler, Medya, Radyo, TV, Sinema, Gazetecilik, Görsel İletişim vb.) farklı fakülteler bünyesinde yer alması sebebi ile iletişim ile ilgili bölümlerin yer aldığı aşağıdaki fakülteler araştırma kapsamına dâhil edilmiştir. 
- İletişim fakülteleri,

- Sanat ve tasarım fakülteleri,

- Sanat, tasarım ve mimarlık fakülteleri,

- Güzel sanatlar, tasarım ve mimarlık fakülteleri,

- Güzel sanatlar ve mimarlık fakülteleri,

- Mimarlık ve tasarım fakülteleri,

- İletişimle ilgili bölümler bulunduran güzel sanatlar fakülteleri,

- İletişim bilimleri fakülteleri,

- İletişimle ilgili bölümler bulunduran işletme fakülteleri (örneğin Haliç Üniversitesi)

- İletişimle ilgili bölümler bulunduran güzel sanatlar fakülteleri (örneğin Işık Üniversitesi)

- Sanat ve sosyal bilimler fakülteleri (örneğin İstanbul Esenyurt Üniversitesi)

- İletişimle ilgili bölümler bulunduran iktisadi, idari ve sosyal bilimler fakülteleri (örneğin İstanbul Gelişim Üniversitesi)

- İletişimle ilgili bölümler bulunduran uygulamalı bilimler fakülteleri (örneğin İstanbul Okan Üniversitesi)

- Sosyal ve beşeri bilimler fakülteleri

Yapılan inceleme sonucunda (Mart 2018 itibarı ile) müfredatlarında bilim iletişimi ile ilgili dersler bulunan fakülte ve bölümler aşağıdaki gibidir:

- Ankara Hacı Bayram Veli Üniversitesi İletişim Fakültesi, Gazetecilik, Halkla İlişkiler, RTS (Radyo, Televizyon ve Sinema) bölümleri müfredatında ortak ders olarak yer alan İLET754 kodlu Bilim ve Teknoloji Gazeteciliği dersi,

- Galatasaray Üniversitesi İletişim Fakültesi müfredatında yer alan COM125 kodlu Bilim ve Teknoloji Tarihi dersi,

- Gaziantep Üniversitesi İletişim Fakültesi, Gazetecilik bölüm müfredatında yer alan GZT208 kodlu Bilim ve Teknoloji Gazeteciliği dersi,

- İbn Haldun Üniversitesi İletişim Fakültesi, Medya ve İletişim bölüm müfredatında yer alan NS101 kodlu Nature and Science I dersi,

- İstanbul Arel Üniversitesi İletişim Fakültesi, Gazetecilik bölüm müfredatında yer alan 605MS14 kodlu Sağlık, Bilim ve Teknoloji Gazeteciliği dersi,

- İstanbul Gelişim Üniversitesi İktisadi ve İdari Bilimler Fakültesi Halkla İlişkiler ve Tanıtım ve Yeni Medya bölümleri müfredatlarında yer alan SBE520 kodlu Bilim Felsefesi ve Metodoloji dersi,

- İzmir Ekonomi Üniversitesi İletişim Fakültesi, Halkla İlişkiler ve Reklamcılık, Medya ve İletişim, Sinema ve Dijital Medya bölümlerinin müfredatında bulunan GED (Genel Eğitim Dersleri: Doğa ve Yaşam Bilimleri alanından; Matematik ve Bilgisayar Bilimleri alanından; İnovasyon ve Girişimcilik alanından; Sosyal Bilimler alanından ),

- Marmara Üniversitesi İletişim Fakültesi, Gazetecilik, Halkla İlişkiler ve Tanıtım ve RTS bölümlerinin müfredatında bulunan BSB2002 kodlu Bilim ve Teknoloji Tarihi dersi,

- Süleyman Demirel Üniversitesi İletişim Fakültesi, Gazetecilik Bölümü müfredatında bulunan GZT409 kodlu Bilim Haberciliği dersi,

- Üsküdar Üniversitesi İletişim Fakültesi, Yeni Medya ve Gazetecilik bölüm müfredatında yer alan YMG358 kodlu Bilim Gazeteciliği dersi. 
Türkiye'deki üniversite sistemin dışında iki devlet kuruluşu daha bilim iletişimcilerinin eğitimi/yetiştirilmesi ile ilgili faaliyetlerde bulunmaktadır. Bunlardan biri resmi haber ajansı Anadolu Ajansı (AA)'dır. Ajans bünyesindeki Haber Akademisi'nde "Savaş Muhabirliğii", "Diplomasi Muhabirliğì" gibi derslerin arasında "İngilizce Enerji Muhabirliği" göze çarpmaktadır (https://www.aa.com.tr/tr/haberakademisi/egitimler)

Bir başka devlet kurumu olan Türkiye Bilimsel ve Teknolojik Araştırma Kurumu (TÜBİTAK) da bilim iletişimi uygulamalarına katkıda bulunmaktadır. Dünya Bilim Gazetecileri Federasyonu (WFSJ) tarafından yürütülen Çevrimiçi Bilim Gazeteciliği Kursu, TÜBITTAK desteğiyle Türkçe olarak da kullanılmaya başlamıştır (http://www.wfsj.org/course/tr/). WFSJ resmi web sitesinden ulaşılan dersler arasında "Bilim Hikâyeleri Bulmak ve Değerlendirmek", "Bilim Nedir?", "Bilim Politikasını Haber Yapmak" ve "Bilimi Nasıl Filme Alırsınız?" gibi başlıklar bulunmaktadır. Dolayısıyla WFSJ eğitimi bilimin nasıl haberleştirilmesi gerektiği ve bunun yöntemini öğretmektedir.

\section{Yazılı Basın}

19.yy.da, Osmanlı basının önde gelen isimlerinden Ahmet Mithat Efendi'nin kişisel çabalarıyla, - ilk olmasa bile- başlayan bilim iletişimi, 20. Yüzyılın ikinci yarısında TÜBİTAK'ın kurulmasıyla resmi bir politika haline gelmiştir. Türkçe basının dünyadaki ilk örneklerinden 200 yıldan daha fazla bir zaman sonra doğmuş olması doğal olarak bilim gazeteciliğinin ortaya çıkışını da geciktirmiştir. "Fert ve toplumların düşünce ve hayat tarzlarını etkileyen bilim ve gazetecilik" (Koloğlu, 1997: VII) bileşeni olarak bilim gazeteciliği henüz Türk basınında bir uzmanlık alanı değildir (s.87). Hâlihazırda Türkiye'de basılan gazetelerin bilim yaklaşımı genellikle sadece "teknoloji haberciliği" ile sınırlı kalmaktadır. Dolayısıyla medyanın toplum ile bilimi buluşturmadaki aracılık rolünü nasıl yerine getirdiği ile ilgili soru işaretleri vardır. 1980'lerden itibaren bilim iletişimi süreçleri ile piyasalaşma hızla iç içe geçmeye başlamıştır. Son 30 yılda ise piyasalaşma baskısı zirveye ulaşmıştır. Ticari yayıncılıkta üretilen içerikler, reklam, pazarlama ve halkla ilişkiler etkinlikleriyle yakınlaşmıştır (Dağtaş ve Yıldız, 2015: 8283).

Diğer yandan, popüler bilim yayıncılığında kamusal yayıncılığın örneği olan Bilim Teknik dergisi bu durumu dengeleyici bir unsur olmaktadır. Dergi, Bilim Sanayi ve Teknoloji Bakanlığı bünyesindeki TÜBİTAK tarafından yayınlanmaktadır. TÜBİTAK kurulduğu günden itibaren yayınladığı kitap ve dergilerle halkın bilim ve teknoloji konularını anlaması/kavraması açısından önemli bir rol oynamıştır. Bu dergilerden Bilim ve Teknik 1967 yılından beri aylık olarak yayınlanmaya devam etmektedir.

Bilim Teknik bilim insanları ve popüler bilim yazarları tarafından hazırlanmaktadır. Dergi ayrıca internet üzerinden de yayınlanmaktadır Gençlere ve yetişkinlere yönelik olarak olan dergi, bilim ve teknoloji alanlarında çalışmayı yaygınlaştırmayı, bilimsel ve teknolojik alandaki çalışmaları halka tanıtmayı, bu alanlara ilgi duyanların aradıkları bilgiyi anlaşılır bir dille anlatmayı amaçlamaktadır. Milli Eğitim Bakanlığı tarafından lise ve dengi okullara tavsiye edilmiş olan dergi, Genel Kurmay Başkanlığı'nca da silahlı kuvvetler personeline tavsiye edilmiştir. (http://www.bilimteknik.tubitak.gov.tr/) 
Devlet sahipliğinde yürütülen ve kar amacı gütmeyen dergiye reklam alınmamaktadır (Dağtaş ve Yıldız, 2015:65-66) Popüler bilim dergileri arasında kamusal yayıncılığın en eski örneği olan dergi halkın bilimsel süreçlere katılımını sağlamayı amaçlamaktadır (s.69).

Dergi, 1990'ların sonunda bilim iletişiminin önemi ile ilgili yayınlarla konuya dikkat çekmeye başlamıştır. Ocak 1997 tarihinde yayınlanan 350. sayının kapak konusu “Bilim Gazeteciliği”"dir (Bilim ve Teknik, 1997). Giriş yazısında Zafer Karaca popüler bilim yayıncılığının gerekliliğini ve önemini şöyle işaret etmektedir: “Bilim gazeteciliği alanında yaşanan boşluğun kökeninde, bilimin toplumumuzda kurumsallaşmaması yatmaktadır. Bilimin düşün ve yaşam biçimi olarak özümsenmediği ve gelenek oluşturamadığı toplumlarda popüler bir tarza ulaşması hem daha güç hem de üstlendiği işleve bakarak çok daha önemlidir. Bu sürecin ve sorunların bileşkesi, ülkemizde popüler bilim yayıncılığının gerekliliğine işaret ediyor."

Yine TÜBİTAK tarafından yayınlanan, üç yaş üzeri çocuklara yönelik aylık dergi Meraklı Minik yedi yaş üzeri çocuklara yönelik Bilim Çocuk ve elektronik dergi (ücretsiz) Bilim Genç dergisi (http://www.bilimteknik.tubitak.gov.tr/) ile her yaştan insana ulaşılmaya çalışılmaktadır.

\section{Bilim ve Televizyon}

Bilim iletişiminde en büyük sorunlardan biri kuşkusuz ki bilginin ve bilgiye ulaşma fırsatının adil dağıtılamıyor oluşudur. Dünyada olduğu gibi Türkiye'de de -tıpkı eğitim olanaklarının adil dağıtılamaması gibi- bilgiye ulaşım olanakları ülke coğrafyası ve ülkenin sosyoekonomik koşullarına bağlı olarak değişim göstermektedir. Ancak şu bir gerçektir ki, özellikle müzeler, bilim merkezleri, hatta bilimsel yayınlar tarafından üretilen fırsat ve bilgi sadece toplumun belli kısmına ulaşabilmektedir. İşte tam da bu noktada kitle iletişim araçlarının, özellikle de televizyonun etkisi yadsınamaz. Televizyon toplumun hemen her kesimi tarafindan ulaşılabilir ve çoğu zaman da en çok tüketilen iletişim aracıdır. Televizyon aracılığı ile her sosyoekonomik düzeyden, her yaştan, her bölgeden ve her eğitim seviyesinden insan bilimsel konular hakkında bilgilendirilebilir.

Türkiye'de ulusal kanallarda bilim ve teknoloji ile ilgili program sayısı oldukça azdır. TRT (Türkiye Radyo Televizyon Kurumu) Belgesel kanalı ve CNN Türk kanalı dışında televizyonda ciddi anlamda bilim programı bulunmamaktadır. Yabancı kanallarda bilim içerikli pek çok program olmakla birlikte bunların seslendirme ya da alt-yazılı olması yani yayın dilinin Türkçe olmaması önemli bir sorundur. Bilim iletişiminin ulusal kanallarda çoğunlukla sağlık iletişimi formatında sınırlı olarak yer aldığı söylenebilir.

Bu açıdan önemli bir adım Orta Doğu Teknik Üniversitesi (ODTÜ) tarafından atılmıştır. ODTÜ 2018-2022 Stratejik Planı çerçevesinde TÜBİTAK'ın desteğiyle hazırlanan TV programı yönetmeninden akademisyen desteğine, tamamıla yerli bir bilim programıdır. Strateji Planı'nda programın amacının halkın bilime ilgisini arttırmak, geliştirmek, en yüksek seviyeye çıkarmak olduğu belirtilmektedir (ODTÜ (tarih): 12). ODTÜ Bilim İletişimi Takımı (Science Communication Team- BİG) tarafından hazırlanan "Bilimin Ev Hali" adlı TV programı 10 Ocak 2019 tarihinde TRT Belgesel kanalında yayınlanmaya başlamıştır. 
Programın her bölümünde farklı bir konu ele alınarak, eğlenceli bir formatta anlatılmaktadır. Program lise öğrencileri ve daha yüksek yaş grubuna yönelik olarak hazırlanmıştır.

\section{Bilim Müzeleri}

Genel olarak, bilim müzeleri, insanların, canlılar, örnekler, modeller, posterler, vb. gibi çeşitli nesneleri zengin şekilde sunan bir ortamda bilimi öğrenmeleri için hizmete konmuş ortamlardır (Chin, 2004). Türkiye' de bu tanıma tam anlamıyla uyan ilk bilim müzesinin tarihi çok daha eskilere dayanmaktadır. Türkiye'de son 20 yılda bilimsel bilginin yayılmasını sağlamak için önemli adımlar atmış olmakla birlikte, ilk doğa tarihi müzesi Maden Tetkik Arama Genel Müdürlüğü (MTA) (1935) bünyesinde 7 Şubat 1968 tarihinde kurulan MTA Tabiat Tarihi Müzesił’dir. Müze, yerbilimlerinin tüm evrelerine ait her türlü materyalin bulunduğu, bilimsel ve eğitsel şekilde sergilendiği bir müzedir (MTA Tabiat Tarihi Müzesi, 2019).

Daha sonra devlet/kamu kurumları bünyesinde çeşitli bilim müzeleri kurulmaya başlamıştır: ODTÜ Bilim ve Teknoloji Koleksiyonu Sergi Alanı (BTKSA) (2003), İslam Bilim ve Teknoloji Tarihi Müzesi (2008), Karşıyaka Bilim Müzesi (2009), Makina ve Kimya Endüstrisi Sanayi ve Teknoloji Müzesi (2013) bu müzelere örnek verilebilir.

TÜBİTAK tarafından gerçekleştirilen etkinlikler arasında bilim merkezleri, bilim şenlikleri gibi etkinlikler de yer almaktadır.

Persson, bilim merkezlerini şu şekilde tanımlamıştır:

“... Bilimi popülerleştirme amacı taşıyan ve halkın bilimsel gösterimlere erişimini să̆layan herhangi bir kurum bilim merkezi olarak kabul edilebilir. Bilim merkezleri bilim ve teknolojiyi uzman olmayanlara açıklamayı amaçlamaktadır. Tipik olarak ziyaretçilerini aktif deneylere dâhil eden etkileşimli gösterimler kullanırlar. Bilim merkezlerinin gösterimleri genellikle "uygulamalı (hands-on)" olarak tarif edilse de bu gösterimler aynı zamanda "beyni" ve "zihni" de sürece dâhil eder; düşüncel süreci başlatır, problem çözmeye ve cevap bulmaya odaklanırlar (Persson, 2000; 10)."

Bir başka tanıma göre bilim merkezi, farklı yaş gruplarından ve farklı birikime sahip bireyleri bilimle buluşturarak, bilim ve teknolojiyi toplum için anlaşılır ve ulaşlır bir hale getirmeyi ve bilim ve teknolojinin önemini toplum gözünde artırmayı amaçlayan; deneysel ve uygulamalı etkinlikler içeren, ziyaretçilerini denemeye ve keşfetmeye teşvik eden; kamu yararı gözeten, kar elde etmek amacıyla kurulmayan, kamu ya da özel sektör kaynakları ile finanse edilen merkezlerdir (Konya Bilim Merkezi, 2019). Bilim merkezlerinin müzelerden en önemli farkı ziyaretçilerine uygulamalı bir deneyim sunuyor olmalarıdır. Bu anlamda, bilim merkezleri, özellikle çocuk ve genç grubundaki bireylere bilimi sevdirmek açısından çok büyük önem taşımaktadırlar.

TÜBİTAK, Strateji Planı çerçevesinde 2008 yılında, kurulacak bilim merkezlerine destek vereceği duyurusunda bulunmuştur. Proje başvuruları arasında yapılan değerlendirme

* Müzenin adı 2017 yılında Şehit Cuma Dă̆ Tabiat Tarihi Müzesi olarak değiştirilmiştir. 
sonucunda ilk olarak Konya Büyükşehir Belediyesi'nin projesi kabul edilmiş, aynı yıl Konya Bilim Merkezi açılmıştır. Daha sonra TÜBİTAK desteği ile 2015'te Elazı̆̆ Bilim Merkezi, 2016'da Kayseri Bilim Merkezi, 2018' de Üsküdar Bilim Merkezi, Bursa Bilim Merkezi, Kocaeli Bilim Merkezi kurulmuştur. 2017 yılı sonu itibariyle bu merkezleri ziyaret eden ziyaretçi sayısı 2 milyon 600 bin iken 2018'in ilk altı ayında ise bu rakam 1,5 milyon kişiye ulaşmıştır (TÜBITAK, 2018).

TÜBİTAK'a bağlı olarak faaliyet gösteren bu bilim merkezlerinin yanı sıra belediyeler ve üniversiteler tarafından kurulmuş 12 bilim merkezi daha faaliyet göstermektedir: Bunlar, Ankara-Ali Kuşçu Bilim Merkezi, Ankara-Feza Gürsey Bilim Merkezi, Ankara-Polatlı Belediyesi Bilim Merkezi ve Uluğ Bey Gökevi, Eskişehir Bilim Deney Merkezi, Gaziantep Gezegenevi ve Bilim Merkezi, İstanbul-Bayrampaşa Belediyesi Bilim Merkezi, İstanbulSancaktepe Bilim Merkezi, İstanbul-Sultangazi Belediyesi Bilim Merkezi, İzmir-Dost Bilim Evi Mevlana Toplum ve Bilim Merkezi, İzmir-Karşıyaka Belediyesi Bilim Merkezi, İzmir- Ödemiş Belediyesi, Deneme ve Bilim Merkezi, KKTC-ODTÜ Kuzey Kıbrıs Kampüs Bilim ve Teknoloji Merkezi'dir.

Türkiye'de bilim ve teknolojinin yaygınlaştırılması ve geliştirilmesi amacıyla atılan bir başka adım ise kamu ve özel sektörü bir araya getirmeyi amaçlayan Türkiye Bilim ve Teknoloji Merkezleri Konferansı'dır. İlk kez 2016 yılında İstanbul'da düzenlenen Bilim ve Teknoloji İletişimi Konferans'tan sonra bu konferanslar TÜBİTAK tarafından düzenli olarak yapılmaya başlanmıştır.

\section{Sonuç/Değerlendirme}

Türkiye'de bilim politikasının temelleri 1960 yıllarla birlikte atılmış, 1963 yılında kurulan Tübitak kuruluşundan 40 yıl sonra “Ulusal Bilim ve Teknoloji Politikaları: 2003-2023” Strateji Belgesi ile ilk resmi bilim politikası belgesini oluşturmuştur. Bu belge ile sadece bilim politikası oluşturmak ve gerçekleştirmek değil, bilimsel bilgi ve teknolojinin kamuya aktarılması, halkın bilimi anlaması/kavramasını sağlamak da TÜBİTAK'ın görevleri arasına girmiştir. Strateji belgesinde belirtildiği üzere "arzu edilen geleceğe" sahip olmak için halkın bilim ve teknoloji konularında yetkinleşmesi ve bunun için de farkındalığının arttırılması gereği düşünülmüştür (TÜBİTAK, 2004:32). Demokratikleşen toplumlarda kamuoyunun öne çıkan önemi halkın da bilimsel bakış açısına sahip olmasını gerektiğini Türkiye'nin de bir gerçeği olarak 21. Yüzyılda kabul etmiştir.

Halkın bilime ilgi duymasını sağlamak, bilimle toplum arasında bağ kurabilmek için en önemli araçlardan biri belki de ilki medyadır. TÜBİTAK'ın popüler bilim yayıncılığ alanındaki faaliyetleri bu açıdan son derece önemlidir.

Reuters haber ajansının 2016 yılında yayınladığı medyada sahte habercilikle ilgili bir rapora göre Türkiye 57 ülke arasında \%49 oranılla sıralamanın en üstünde yer almaktadır (teyit.org, 2018). Dolayısıyla, Türkiye açısından en azından bilimsel konularda farkındalığın yükseltilmesinin ne kadar önemli olduğu açıcça görülmektedir. Medya -yani bilim iletişimini yapanlar- bilimi yaratanlar kadar önemlidir çünkü halkın bilimsel bilgilere ulaşması çok büyük oranda medya aracılığıyla olmaktadır. Yazılı basın, televizyon ya da internet siteleri 
yazarlarının (muhabir/gazeteci/haberci), bilimsel konuları doğru ve anlaşılır bir şekilde bilim insanı olmayan kişilere aktarmaları bu yüzden büyük önem taşımaktadır.

Bu açıdan, YÖK'ün 2012 yılında üniversitelerde bilim iletişimi/bilim muhabirliği eğitimine dikkat çekmeyi amaçlayan yönlendirmesi son derece önemlidir. Ancak bu çalışma, o zamandan bugüne geçen süre içinde üniversitelerde bilimi iletişimine yönelik çalışmaların çok yavaş ilerlediğini göstermiştir. Bugün Türkiye'de sadece 10 üniversitede bilim iletişimi ile ilgili ders bulunduğu anlaşılmaktadır.

Bilim iletişiminin gerçekleştiği alanlardan biri de bilim merkezlerdir. Bilimi ulaşılır kılmak, halkın gözünde bilimin önemini arttırmak, bilimsel konularda farkındalık yaratmak açısından bilim merkezleri özellikle TÜBİTAK'ın büyük önem verdiği araçlardan biri olmuştur. 2008 yılından itibaren Konya, Kayseri, Bursa, Elazı̆̆, Üsküdar (İstanbul), Kocaeli belediyeleri tarafından TÜBİTAK ortaklığıyla bilim merkezleri açılmıştır. Bu merkezlerde gezici sergiler, bilim gösterileri, eğitim atölyeleri gibi etkinliklerde çocuk ve yetişkinleri bilimi deneyimlemesi mümkün olmuştur. TÜBİTAK'ın desteklediği bilim merkezlerinin yanı sıra özellikle belediyelerin öncülüğünde de bilim merkezleri açılmıştır ve açılmaya devam etmektedir.

Toplum ile bilim arasında en önemli köprü olarak televizyon, bilim iletişimin gerçekleştirildiği belki de en etkili araçtır. TÜBİTAK'ın desteğiyle ODTÜ tarafından hazırlanan ilk yerli bilim programı "Bilimin Ev Hali” 2019 yılının ilk günlerinde TRT Belgesel kanalında yayınlanmaya başlamıştır.

Resmi bilim politikaları çerçevesinde, yukarıda özetlenen bilim iletişimi politikasına dair gelişmeler Türkiye'nin bu konuda, gelişmiş Batı ülkelerinden geri kalmış olmasına rağmen arayı kapatmak için hızlı adımlar atma çabasını göstermektedir.

Cornell Üniversitesi tarafından yayınlanan "Public Understanding of Science” (Halkın Bilimi Anlaması) adlı derginin editörü Bruce Lewenstein halkın bilimi anlamasını neyin geliştireceği hakkında ortak bir görüş olmadığını dile getirir (2003:1). Lewenstein bir toplum için böyle bir belirsizlikten söz ederken, farklı toplumların farklı geçmiş, kültür ve düşünce yapısına sahip oldukları düşünüldügün̈le bu durum da açılık kazanmaktadır. Bugün, 2000 yılı sonrası Türkiye' de bilim iletişimi adına atılmış adımlar, başvurulan yöntemler ne kadar önemli olsa $\mathrm{da}$, insanların bilimin önemini anlasa bile bilimsel düşünme, bilimsel bilgileri karar alma süreçlerine katılmak için değerlendirebilmeleri tek başına yukarıda sıralanan gelişmelere bağlı değildir.

Bilim iletişimini gerçekleştiren kaynaklar ne kadar çeşitli olsa da (müzeler, bilim merkezleri, bilim festivalleri, konferanslar gibi) bugün Türkiye' de en önemli haber kaynağı televizyondur (Reuters, 2019:114). Çocukların çevreleriyle ilgili bilgilerin \%83'ünü medya aracılığıyla edindikleri, hatta bilim insanlarının bile bilimsel gelişmeleri kitle iletişim araçlarından ve internet üzerinden aldıkları (Hayes \& Grossman, 2010) düşünülürse medyanın bilim iletişimi açısından önemi daha da iyi anlaşılabilir.

Bilim iletişimi eğitimi Çin, Hindistan, Avustralya gibi pek çok ülkede üniversitelerin sadece lisans değil yüksek lisans ve doktora programlarında da yer almaktadır (Gascoigne ve 
Metcalfe, 2017:10). Bu açıdan, bilim iletişiminde, medyada çalışacak insanları/habercileri yetiştirecek olan üniversitelerin rolü çok önemlidir. Yükseköğretim Kurulu (YÖK) verilerine göre Türkiye'de Temmuz 2019 itibarı ile 207 üniversite bulunmaktadır (Yüksek Öğretim Kurulu, 2019). Bu üniversiteler bünyesinde yer alan iletişim fakülteleri ve ilgili fakültelerin sayısı göz önüne alındığında, bilim iletişimi ile ilgili ders sayısının (10) azlığı dikkat çekicidir. Diğer yandan Fahy ve Nisbet bilim gazetecilerinin bilimsel sonuçları aktarma, analitik ve eleştirel olabilmeleri için gazetecilik becerisi kadar bilimsel bilgiye de sahip olmaları gerektiğini söyler (akt. Cassany, Cortinas ve Elduque, 2018: 11). Kurtuluş (1997:18) da kamuoyunun bilimsel verilere duyarlılığının sağlanmasındaki en önemli iki araçtan birinin (diğeri basının bilimsel konulara ağırlık vermesidir) "zorunlu temel eğitimde fen derslerinin etkin kılınması" demektedir. Bilim muhabirliği bağlamında düşünüldüğünde, iletişim fakültelerinde de temel fen bilimleri derslerinin, bu alana kaymayı düşünen öğrenciler için seçmeli olması düşünülebilir. Diğer yandan, bilim iletişimi alanında çalışacak gazeteci adaylarının, İngilizceye, en azından anlayabilecek düzeyde hâkim olmaları, birer bilim insanı olmasalar da bilimsel bilgiye nasıl ulaşacaklarını ve ulaştıkları bilgiyi halka sade ve anlaşılır bir dille nasıl aktaracaklarını bilmeleri açısından çok önemlidir.

Dolayısıyla, YÖK'ün 2012'de bilim iletişimini geliştirmek için başlattığı girişimin henüz bir ilerleme kaydettiği söylenemeyeceği gibi yakın zamanda önemli gelişme kaydetmesi beklenmemelidir. Özellikle bu dersleri verecek kişilerin, bugün mevcut olan ve-konu çok yeni olduğu için - bilim iletişimi alanında daha önce eğitim almamış olan akademisyenler oldukları ya da fen, doğa bilimleri gibi bilimlerde eğitim almadıkları düşünülürse, genç gazetecilerin eğer istiyorlarsa, kendi gayretleriyle bilim ve teknoloji konularında uzmanlaşmaya çalışmaları gerekecektir.

Bilim gazeteciliği eğitimiyle ilgili Batı'da farklı örneklere de rastlanmaktadır. Örneğin ABD'de, Massachusetts Teknoloji Enstitüsü (MIT) tarafından verilen Knight Bilim Muhabirliği bursu, gazetecilere bilim yazarlığı becerisi kazandırmak üzere bir ders yılı boyunca seminerler vermekte ve laboratuvar gezileri sağlamakta ve ileri düzeyde fen derslerini izlemelerine imkân tanımaktadır (Hayes ve Grossman, 2010:5). Bir diğer uygulama da bilim insanlarının gazetecilik eğitimi alması ve gazetecilerin bakış açılarını anlamaları ve çalışmalarını halkın anlayacağı şekilde yazıya dökebilmeleri için verilen burslardır. Amerikan Bilim Geliştirme Derneği 1975 yılından beri lisansüstü fen ve mühendislik öğrencilerine medya kuruluşlarında yaz bursları sağlamakta, İngiltere' de 1987 yılından beri her yıl on kadar bilim insanı gazetecilik burslarıyla medya kuruluşlarına gönderilmektedir (s.5-6).

Bu örnekler bugün için Türkiye'de gerçekleştirilebilecek uygulamalar olmaktan uzak görünmektedir. Medyanın üretim yapısı buna uygun olmadığı gibi her halde ne mühendislik öğrencileri iletişimci olmak isterler ne de Türkiye'deki eğitim sistemi içinde mühendislik öğrencilerinin kendi ana dilinde yazma/ifade becerisi vardır. Bu gerçeği OECD (Ekonomik Kalkınma ve İşbirliği Örgütü)'nin PISA(Uluslararası Öğrenci Değerlendirme Programı) testleri de ortaya koymaktadır. OECD'nin PISA anketi 90'dan fazla ülkede üç yıllık dönemlerde uygulanan, öğrencilerin okuma, matematik ve bilim alanlarındaki bilgi ve becerilerini ölçmek için kullanılan uluslararası bir ankettir. 2018 PISA sonuçları henüz açıklanmamış olmakla birlikte, 2015 yılı sonuçlarına bakılırsa, Türkiye değerlendirmeye katılan 70 ülke içinde matematikte 49., okumada 50. ve fende 52. sırada yer almaktadır (PISA, 
2015). Oysa bilimsel okuryazarlık, bilimsel fenomenleri açıklayabilmeyi, bilimsel araştırmayı değerlendirmeyi ve tasarlamayı, veri ve kanıtları bilimsel olarak yorumlamayı içerir (OECD, 2017).

Sonuç olarak, son yirmi yılda bilim iletişimi alanında ortaya çıkan gelişmeler önemli olsa da bilimin halkla buluşmasının önünde birçok sorun vardır. Örneğin Türk basınında sahte haber oranındaki yükseklik bunlardan biridir. Buna rağmen, uluslararası haber kuruluşu Reuters' in 2019 raporuna göre Türkiye'de basına duyulan güven \%8 oranında artmıştır (Reuters, 2019:115) ki bu iki verinin aynı anda var olması da başlı başına bir sorundur. Dijital uçurum olarak da adlandırılan, cinsiyet, sosyoekonomik durum, coğrafya vb. gibi farklılıklar sebebi ile bilgi teknolojilerinin mülkiyet, ulaşılabilirlik ve kullanılabilirliğinin eşitsizlik göstermesi durumu da Türkiye'nin bir gerçeğidir. Türkiye' nin batısında yaşayan bir birey ile doğusunda yaşayan bir bireyin bilgi teknolojilerine, dolayısıyla da bilime ve bilim haberlerine ulaşabilirliği kuşkusuz ki farklılık göstermektedir. 2018 yılında Open Society Institute tarafından yapılan bir araştırmaya göre (Open Society Institute Sofia, 2018) Türkiye medya okuryazarlığı konusunda 35 Avrupa Birliği ülkesi içerisinde 16 puanla sondan ikincidir (Birinci 76 puan ile Finlandiya). Dolayısıyla, bilim iletişimi alanındaki sorunları tek bir faktör üzerinden açıklamak ve çözümlemek mümkün değildir. Bu alandaki sorunlar çeşitli toplumsal sorunlardan bağımsız düşünülemez; örneğin eğitim bunlardan biridir: İletişim fakültelerine sözel temelli öğrenci alımı buradaki sorunların en önemlilerinden biridir. Mantık ve yeterince matematik okumadan bölüme giren öğrenci herhangi bir bilgiyi, sorunu analiz/sentez yapma ve eleştirel düşünme becerisinden yoksundur; olay ve olgulara merak ve şüphe ile yaklaşmamaktadır -ki merak ve şüphe bilimin en önemli iki unsurudur. Diğer yandan işsizlik de genç nüfusun en önemli sorunudur. Genç iletişimciler medyada iş bulmak için doğal olarak toplumun en az ilgilendiği alandan (bilimden) uzak durmak, daha popüler olan siyaset ve magazine yönelmek isteyeceklerdir. Toplam gazete-dergi sayısının 2013'ten 2017 yılına \%33 düştüğü (Reuters, 2019:114) düşünülürse medyada bilim iletişiminin bir uzmanlık alanı olmaması bir yana var olan bilim haberlerinin sayısında da belirgin bir düşüş olduğu kesindir. Özellikle yazılı basında yer bulan ve "bilim ve teknoloji iletişimi" olarak addedilen içerik de sağlık ve teknoloji ağırlıklıdır, zira halk genel olarak sağlık ve teknoloji haberlerine ilgi göstermekte, astronomi, fen bilimleri, matematik vb. alanlarda ise büyük bir boşluk bulunmaktadır. Bilim iletişiminde arz-talep dengesi ticari kaygılar sebebi ile talep yönüne kaymıştır.

\section{Kaynakça}

Akoğlu, A. (2011). Bilim İletişimi. Bilim ve Teknik, Ağustos, pp. 24-30.

$\begin{array}{ccccc}\text { Anadolu } & \text { Ajansı } & (2019) . & \text { Anadolu Ajansı Haber Akademisi. } \\ \text { Erişim } & & \text { adresi: } & \text { https://www.aa.com.tr/tr/haberakademisi/egitimler }\end{array}$

(Erişim tarihi: 13 Temmuz 2019).

Bauer, M. W. ve diğerleri (2013). Global Science Journalism Report: Working Conditions \& Practices, Professional Ethos and Future Expectations. (Erişim tarihi

Erişim adresi: http://eprints.lse.ac.uk/48051/1/Bauer Global science journalism 2013.pdf (Erişim tarihi: 5 Nisan 2019). 
Burakgazi, S. G. (2017). Kritik Olaylar, Politik Dokümanlar, Raporlar ve Araştırmalar Işı̆̆ında Türkiye'de Bilim İletişimi. Selçuk İletişim, Temmuz, 10(1), pp. 232-261.

Burns, T. W., O'Connor, D. J. \& Stocklmayer, S. M. (2003). Science Communication: A Contemporary Definition. Public Understanding of Science, Issue 12, pp. 183-202.

Cassany, R., Cortinas, S. \& Elduque, A. (2018). Communicating Science: The Profile of Science Journalists in Spain. Merdia Education Research Journal, XXVI(55), pp. 9-17.

Chin, C.-C. (2004). Museum Experience - a Resource for Science Teacher Education. International Journal of Science and Mathematics Education, 2(1), pp. 63-90.

Dağtaş, E. \& Yıldız, M. E. (2015). Türkiye'de Popüler Bilim Dergilerinin Eleştirel Ekonomi Politik Çözümlemesi: "Bilim ve Teknik" ile "Popular Science" Örnekleri. Akdeniz Üniversitesi İletişim Fakültesi Dergisi, Aralık, Issue 24, pp. 56-86.

Dursun, Ç. (2010). Dünyada Bilim İletişiminin Gelişimi ve Farklı Yaklaşımlar: Toplum İçin Bilimden Toplumda Bilime. Kurgu Online International Journal of Communication Studies, Cilt 2.

Dursun, O. (2018). Bilim Gazeteciliğinde Popülaritenin ve Pozitif Bilimlerin Hegamonyası. İletişim Dergisi, Aralık, say1 29 pp. 83-114.

Dünya Bilim Gazetecileri Federasyonu (2019). Çevrimiçi Bilim Haberciliği Kursu. Erişim adresi: http://www.wfsj.org/course/tr/(Erişim tarihi: 13 Temmuz 2019].

Elmacı, İ. (2015). Bilim Politikası Çalışmalarında Bütünsellik Arayışı ve "Türk Bilim Politikası 19832003". Ankara Üniversitesi Dil Tarih ve Coğrafya Fakültesi Dergisi, , 55(1), pp. 55-68.

Erdoğan, İ. (2007). Türkiye'de Gazetecilik ve Bilim İletişimi. 1. Baskı. Ankara: G.Ü. İletişim Araştırmaları Merkezi.

Fahy, D. ve Nisbet, M. C. (2011). The Science Journalist Online: Shifting Roles and Emerging Practices. Journalism, 12(7), pp. 778-793.

Fuller, S. (1999). The Governance of Science: Ideology and the Future of the Open Society, Buckingham, Philadelphia: Open University Press.

Hayes, R. \& Grossman, D. (2010). Bilim İnsanının Medya Rehberi. 3. baskı. Ankara: TÜBİTAK.

Gascoigne, T. ve Metcalfe, J. (2017). 'The Emergence Of Modern Science Communication in Australia'. JCOM 16 (03), A01.

Koloğlu, O. (1997). Halka Doğru Bilim Türkiye'de Bilim Gazeteciliği. İstanbul: Türk Tarih Kurumu Yayınları.

Konya Bilim Merkezi, 2019. Bilim Merkezi Nedir ?. Erişim adresi: https://www.kbm.org.tr/Default/PageDetails2/75d81796-64ec-e611-80e9-

005056950aeb/11cdbd68-55cb-e611-80e9-005056950aeb

(Erişim tarihi: 27 Temmuz 2019].

Kurtuluş, Ö. (1997). Bilim Gazeteciliği. Bilim ve Teknik, Issue 350, pp. 18-24.

Lewenstein, B. (2003). Models of Public Communication of Science and Technology. Erişim adresi: https://ecommons.cornell.edu/xmlui/bitstream/handle/1813/58743/Lewenstein.2003.Models of communication.CC\%20version\%20for\%20Cornell\%20eCommons.pdf?sequence $=3$ (Erişim tarihi: 18 Temmuz 2019). 
Lynch, J. ve diğerleri (2014). Bridging Science and Journalism: Identifying the Role of Public Relations in the Construction and Circulation of Stem Cell Research Among Laypeople. Science Communication, 36(4), pp. 479-501.

Metcalf, J. ve Gascoigne, T. (1995). Science Journalism in Avustralia. Public Understanding Science, Cilt 4, pp. 411-428.

MTA Tabiat Tarihi Müzesi (2019). MTA Tabiat Tarihi Müzesi. Erişim adresi: http://www.kulturvarliklari.gov.tr/TR-43990/ankara---sehit-cuma-dag-tabiattarihi-muzesi.html (Erişim tarihi: 23 Temmuz 2019].

Murcott, T. H. ve Williams, A. (2012). The Challenges for Science Journalism in the UK. Progress in Physical Geography, 37(2), pp. 152-160.

Nelkin, D. (1987). The Culture of Science Journalism. Society, September/October.pp. 17-25.

Nelkin, D. (1994). Bilim Nasıl Satılır. İstanbul: Şule Yayınları.

ODTÜ (2018). ODTÜ Strateji Planı 2018-2022, Ankara: ODTÜ.

Open Society Institute Sofia (2018). Common Sense Wanted - Resilience to "Post-Truth" and Its Predictors in the New Media Literacy Index 2018, Soifa: Open Society Institute.

Persson, P.-E. (2000). Community Impact of Science Centers: Is There Any?. Curator, 43(1), pp. 917.

Reuters (2019). The Reuters Institute Digital Report 2019. Erişim adresi: http://www.digitalnewsreport.org/ (Erişim tarihi: 04 Temmuz 2019).

Royal Society (1985). The Public Understanding of Science, Bedfordshire: Royal Society.

teyit.org (2018). Araştırma: Türkiye sahte habere en çok maruz kalan ülke. Erişim adresi: https://teyit.org/turkiye-sahte-habere-en-cok-maruz-kalan-ulke/

(Erişim tarihi: 27 Temmuz 2109).

teyit.org (2018). Araştırma: Türkiye sahte habere en çok maruz kalan ülke. Erişim adresi: https://teyit.org/turkiye-sahte-habere-en-cok-maruz-kalan-ulke/ (Erişim tarihi: 27 Temmuz 2019).

TÜBİTAK Bilim, Teknoloji ve Yenilik Politikaları Daire Başkanlığı (2010). 2011-2016 Bilim ve Teknoloji İnsan Kaynağı Stratejisi ve Eylem Planı, Ankara: TÜBİTAK.

TÜBİTAK (2004). Ulusal Bilim ve Teknoloji Politikalarn 2003-2023 Strateji Belgesi. basım yeri bilinmiyor:Türkiye Bilimsel ve Teknik Araştırma Kurumu.

TÜBİTAK (2019). Bilim Teknik. Erişim adresi: http://www.bilimteknik.tubitak.gov.tr/ (Erişim tarihi: 12 Temmuz 2019).

TÜBİTAK (2019). ТÜВİТАK. Erişim adresi: https://www.tubitak.gov.tr/tr/icerik-hakkimizda (Erişim tarihi: 12 Temmuz 2019).

Yüksek Öğretim Kurulu (2019). Üniversitelerimiz. Erişim adresi: https://www.yok.gov.tr/universiteler/universitelerimiz

(Erişim tarihi: 27 Temmuz 2019). 